\title{
Detection of MBL-2 gene expression in intestinal biopsies of celiac patients by in situ reverse transcription polymerase chain reaction
}

\author{
M. Boniotto, ${ }^{*}$ O. Radillo, ${ }^{\S}$ L. Braida, ${ }^{*}$ D. Pirulli, ${ }^{*}$ A. Città, ${ }^{\circ}$ T. Not, ${ }^{\circ}$ A. Amoroso, ${ }^{*}$ S. Crovella* \\ *Unità di Genetica; ${ }^{\circ}$ Unità di Pediatria; Dipartimento di Scienze della Riproduzione e dello Sviluppo, \\ Università di Trieste; §IRCCS Burlo Garofolo, Laboratorio Analisi, Trieste, Italy
}

\section{(C)2003, European Journal of Histochemistry}

Correspondence: Sergio Crovella, Dipartimento di Scienze della Riproduzione e dello Sviluppo, Unità di Genetica, Università di Trieste, via dell'Istria 65/1, 34137 Trieste, Italy. Phone: international +39.040 .3785538 . Fax: international +39.040.3785210. E-mail: crovella@burlo.trieste.it

Key words: celiac disease, MBL2, MBP, RT in situ PCR, apoptosis, autoimmunity

Paper accepted on March 19, 2003.

European Journal of Histochemistry

2003; vol. 47 issue 2 [Apr-Jun]:177-180

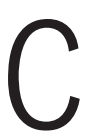
eliac disease (CD) is an autoimmune enteropathy triggered by ingestion of gluten in genetically susceptible subjects and represents one of the most frequently occurring, treatable, lifelong autoimmune disorders. Undetected or untreated $C D$ may cause late more severe complications (Farrell and Kelly, 2002). So far, several factors have been identified as possible agents responsible for $C D$. There is a strong evidence that $C D$ is associated with specific HLA haplotypes (HLADQA1* 0501, DQB1*0201 or DQA1*0301, DQB0302) (Sollid and Thorsby, 1993). Recently it has been demonstrated on Italian patients that polymorphisms of the first exon of MBL2 gene, which encodes for Mannose Binding Protein (MBP), could play a pathophysiological role in celiac disease (Boniotto et al., 2002). MBP is a serum protein involved in the natural or innate immune response. MBP acts as an ante-antibody and can enhance opsonisation, or can activate the classical pathway of the complement on bacteria, viruses and fungi (Sastry and Ezekowitz, 1993). MBP seems to be involved in autoimmune diseases such as systemic lupus erythematosus (Garred et al., 1999; Villarreal et al., 2001), ulcerative colitis and
Crohn's disease (Rector et al., 2001), rheumatoid arthritis (Jacobsen et al., 2001; Saevarsdottir et al., 2001) and Sjogren's syndrome (Tsutsumi et al., 2001; Wang et al., 2001). These findings support the hypothesis that MBP has an important role in regulating the immune response. $\mathrm{MBP}$ is known to be produced by liver epathocytes and its constitutional level in the circulation is very stable ( Nielsen et al., 1995), whereas the level among different individuals varies from below $50 \mathrm{ng} / \mathrm{mL}$ to above 3 $\mu \mathrm{g} / \mathrm{mL}$.

In our study we investigated MBL2 gene expression, which encodes for MBP, in intestinal biopsies of celiac patients using in situ reverse transcription polymerase chain reaction (RT-PCR).

Frozen intestinal biopsies, from 15 celiac patients (diagnosis of celiac disease was performed following the ESPGHAN indications (Walker-Smith et al., 1990) were collected from the gastroenterology unit of IRCCS Burlo Garofolo. Intestinal biopsies were fixed on SuperFrost slides, rehydrated to nuclease-free water through graded fresh acqueous solution of ethanol $(100 \%, 90 \%, 80 \%)$ then permeabilized in a $0.01 \%$ Triton-X $100 / \mathrm{PBS}$ solution for $2 \mathrm{~min}$, and rinsed in PBS for 2 min.

After permeabilization, tissues were treated with RNAase-free DNAase (Celbio, Milan, Italy) (50 U) at $37^{\circ} \mathrm{C}$ overnight. Reverse Transcription and MBL2 cDNA amplification were performed by using RT PCR Core kit (Applera, Italia, Milano). Primers for MBL2 cDNA amplification were: forward 5'-ACCAGGCCAAGGGCTCAG-3', reverse 5'AAGGTGAGCCACTTTTTGATACGT-3'. Five $\mu \mathrm{M}$ dUTP Cy3 fluorescent nucleotides (Amersham Pharmacia) were used for direct labelling of the amplicon. The direct fluorescent in situ PCR was performed using the following cycle: denaturation at $94^{\circ} \mathrm{C}$ for $30 \mathrm{sec}$, annealing at $53^{\circ} \mathrm{C}$ for $1 \mathrm{~min}$ and extension at $72^{\circ} \mathrm{C}$ for 1 min, repeated 15 times. After the PCR reaction slides were washed twice with PBS for 5 min and then counter-stained with 

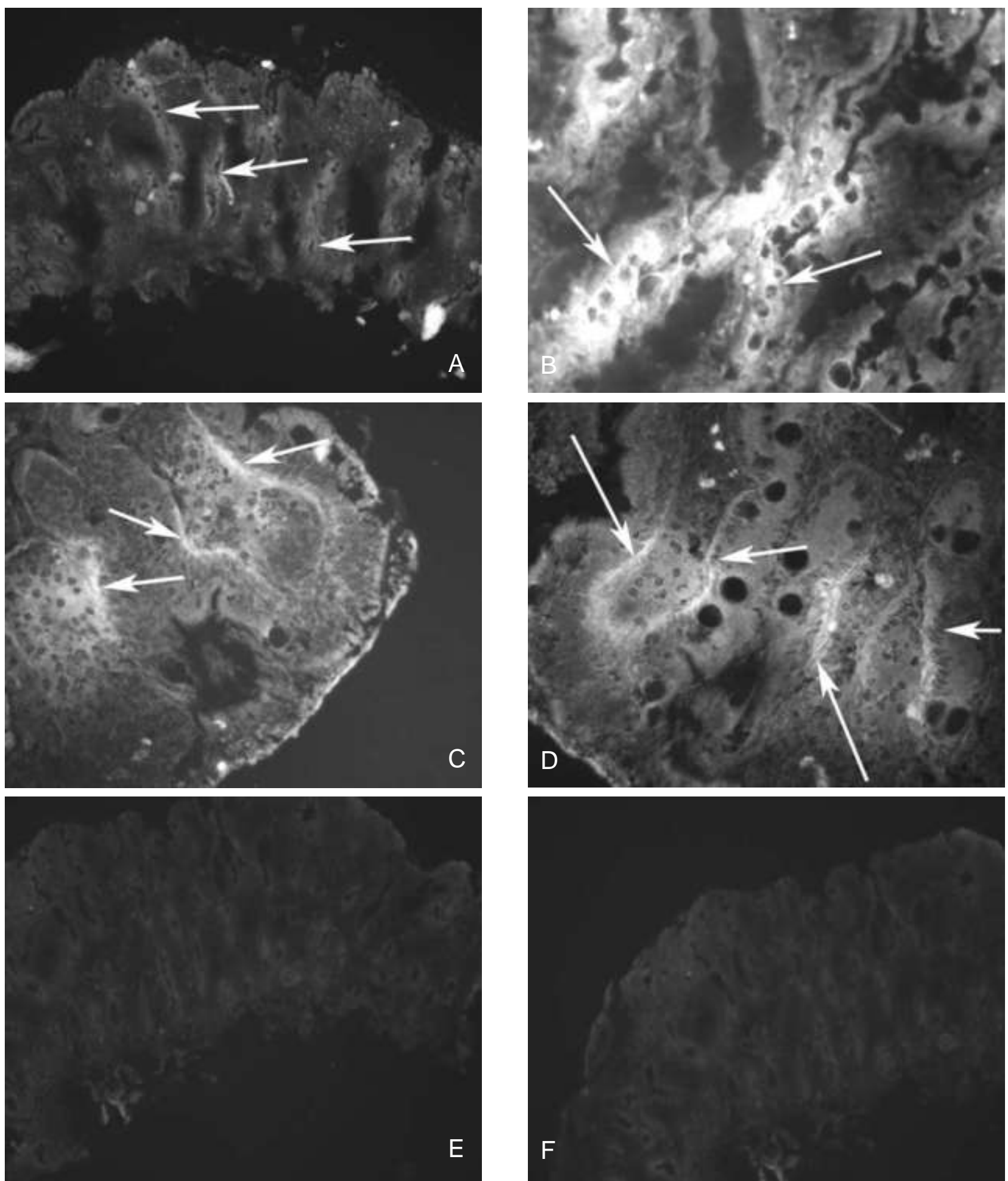

Figure 1. a) MBL2 gene expression revealed by RT in situ PCR: MBL2 cDNA amplification signal is localized at the level of the criptae (arrows) in the intestinal biopsy of a celiac patient. Magnification is 100X. b) MBL2 amplification signal localization in the area surrounding an intestinal cripta (arrows). Magnification is 400X. c,d) MBL2 gene expression in a celiac patient: the amplification signal is localized in the area near the basal lamina and the criptae (arrows). Magnification is 400X. e) Negative control (no RT): no fluorescent signal of amplification is detectable. Magnification is 100X. f) Negative control (no primers): no aspecific signal due to Taq polymerase gap filling and nick repair activity is visible. Magnification is 100X. 

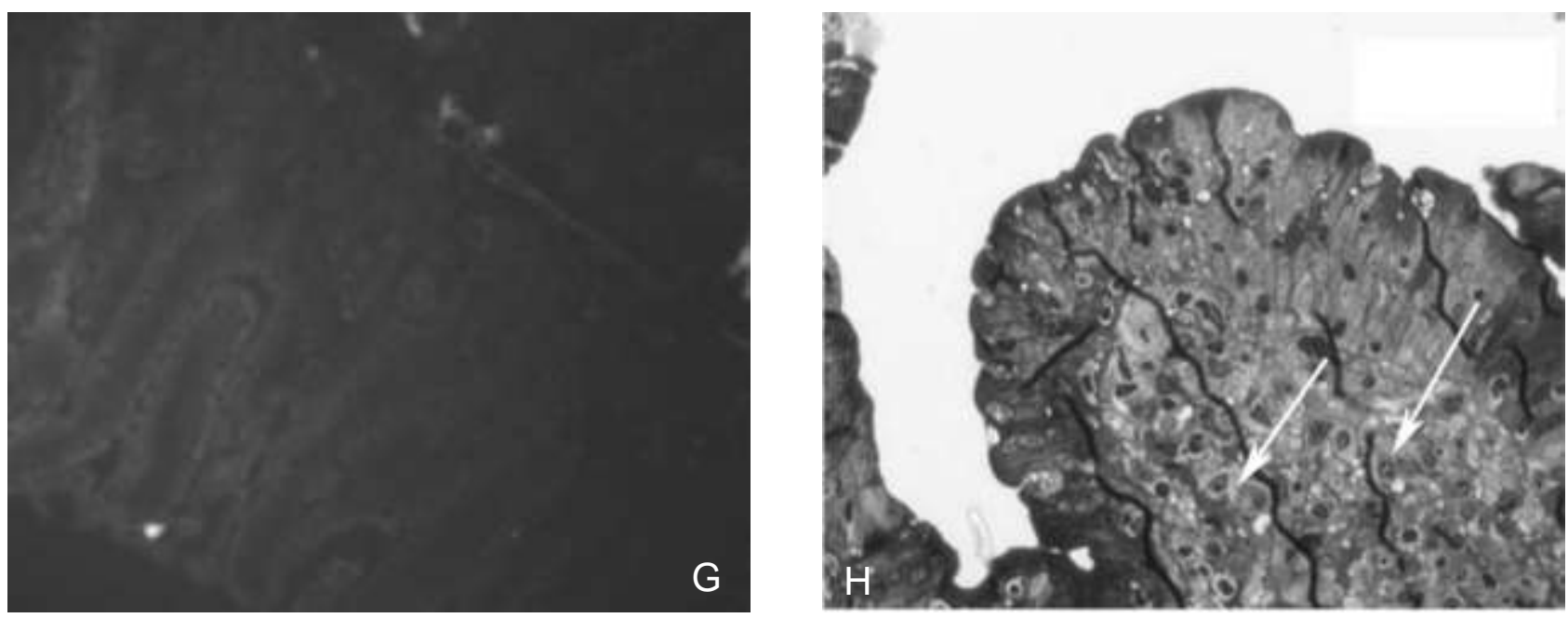

Figure 1 (continued). g) Healthy individual control: no MBL2 gene expression was detected. Magnification is 100X. h) Intestinal biopsy of a celiac patient counterstained with Ematoxil-Eosin: cells of the immune response (both acquired and innate) are localized near to the basal lamina (arrows). Magnification is 400X.

DAPI (Vectashield, Burlingame, CA, USA) and directly observed under a fluorescent microscope (Olympus Optical, Shinjuku-ku, Tokyo, Japan). Negative controls were used for RT and IS-PCR, without either RT or primers. Four intestinal biopsy from healthy individuals were used as controls.

Our results show that MBL2 gene is clearly expressed in intestinal biopsies of celiac patients. In fact, as shown in Figure 1, we have found a positive signal of MBL2 cDNA amplification (Figure la, $1 b, 1 c, 1 d$ ) in correspondence of the criptae and in correspondence of the basal lamina of the intestinal epithelium. Both no RT (Figure 1e) and no primer (Figure $\mathrm{lf}$ ) controls were characterized by absence of amplification signal. No amplification signal was detected in the intestinal biopsy from healthy individuals (Figure $1 \mathrm{~g}$ ). These results demonstrates that MBL2 expression is enhanced in intestinal tissues taken from celiac patients, instead it is absent in healthy individuals. Localization of the signal allow us to hypothesizing that MBL2 is not expressed by intestinal epithelial cells, but it is expressed in cells of the immune response (both acquired and innate) which are usually localized in this area in intestine of patients suffering from celiac disease (Figure 1h). Several authors have reported as data not shown MBL2 gene expression in cells of the innate immune response such as monocyte/macrophages and recently it has been demonstrated that MBP plays a key role in the clearance and removal of apoptotic, damaged and necrotic cells (Ogden et al., 2001). As already described by Boniotto et al. (2002) MBL2 seems to play a role in development of celiac disease either influencing the removal of apoptotic and necrotic cells of immune response in intestine or partecipating to immune response against pathogens in this area. Localization of a clear signal for MBL2 gene in patients suffering from celiac disease and the absence of expression in healthy individuals suggest that MBL2 is not constitutively expressed in intestine for taking part in immune response in healthy individuals, but it is up-regulated in intestine of celiac patients after a stimulus, that is not known yet. In our knowledge, this stimulus could done by apoptotic and necrotic cells of celiac people. Further studies would be necessary to understand the role of $\mathrm{MBL}$ in intestine of celiac patients, to isolate cells expressing MBL2 gene and to identify the stimulus for protein expression.

\section{Acknowledgements}

This work was supported by a MIUR grant (COFIN 2001). M. Boniotto and D. Pirulli are recipients of a long-term fellowship from Trieste University.

\section{References}

Boniotto M, Braida L, Spano A, Pirulli D, Baldas V, Trevisiol C, et al. Variant mannose-binding lectin alleles are associated with celiac disease. Immunogenetics 2002;54:596-8.

Farrell RJ, Kelly CP. Celiac sprue. N Engl J Med 2002;346:180-8.

Garred P, Madsen HO, Halberg P, Petersen, J, Kronborg, G, Svejgaard, $A$, et al. Action in systemic lupus erythematosus. Arthritis Rheum 1999;42:2145-52. 
Jacobsen S, Madsen HO, Klarlund M, Jensen T, Skjodt H, Jensen KE, et al. The influence of mannose binding lectin polymorphisms on disease outcome in early polyarthritis. TIRA Group. J. Rheumatol $2001 ; 28: 935-42$

Nielsen SL, Andersen PL, Koch C, Jensenius JC, Thiel S. The level of the serum opsonin, mannan-binding protein in HIV-1 antibody-positive patients. Clin Exp Immunol 1995;100:219-22.

Ogden CA, de Cathelineau A, Hoffmann PR, Bratton D, Ghebrehiwet B Fadok VA, et al. Clq and mannose binding lectin engagement of cell surface calreticulin and CD91 initiates macropinocytosis and uptake of apoptotic cells. J Exp Med 2001;194:781-95.

Rector A, Lemey P, Laffut W, Keyaerts E, Struyf F, Wollants E, et al. Mannan-binding lectin (MBL) gene polymorphisms in ulcerative colitis and Crohn's disease. Genes Immunol 2001;2:323-8.

Saevarsdottir S, Vikingsdottir T, Vikingsson A, Manfredsdottir V, Geirsson AJ, Valdimarsson H. Low mannose binding lectin predicts poor prognosis in patients with early rheumatoid arthritis. A prospective study. J Rheumatol 2001;28:728-34.

Sastry K, Ezekowitz RA. Collectins: pattern recognition molecules involved in first line host defense. Curr Opin Immunol 1993;5:59-66.
Sollid LM, Thorsby E. HLA susceptibility genes in celiac disease: genetic mapping and role in pathogenesis. Gastroenterology 1993; 105: 910-22.

Tsutsumi A, Sasaki K, Wakamiya N, Ichikawa K, Atsumi T, Ohtani K, et al. Mannose-binding lectin gene: polymorphisms in Japanese patients with systemic lupus erythematosus, rheumatoid arthritis and Sjogren's syndrome. Genes Immunol 2001;2:99-104.

Villarreal J, Crosdale D, Ollier W, Hajeer A, Thomson W, Ordi J, et al. Mannose binding lectin and FcgammaRIIa (CD32) polymorphism in Spanish systemic lupus erythematosus patients. Rheumatology 2001;40:1009-12.

Walker-Smith JA, Guandalini S, Schmitz J, Shmerling DH, Visakorpi JK. Revised criteria for diagnosis of celiac disease: report of working group of European Society of Paediatric Gastroenterology and Nutrition. Arch Dis Child 1990;65:909-11.

Wang ZY, Morinobu A, Kanagawa S, Kumagai S. Polymorphisms of the mannose binding lectin gene in patients with Sjogren's syndrome. Ann Rheum Dis 2001;60:483-6. 